\title{
Perspectives of Afghan refugee mothers on the experience of caring for a child with cancer: a qualitative analysis
}

\author{
Lida Nikfarid, ${ }^{1}$ Maryam Rassouli, ${ }^{2}$ Azam Shirinabadi Farahani, ${ }^{1}$ Raziyeh Beykmirza ${ }^{3}$ and Tahereh Alsadat Khoubbin Khoshnazar ${ }^{4}$
}

${ }^{1}$ Department of Pediatric Nursing, School of Nursing and Midwifery, Shahid Beheshti University of Medical Sciences, Tehran, Islamic Republic of Iran. ${ }^{2}$ Cancer Research Center, Shahid Beheshti University of Medical Sciences Tehran, Islamic Republic of Iran. ${ }^{3}$ Nursing and Midwifery Care Research Center, School of Nursing \& Midwifery, Tehran University of Medical Sciences, Tehran, Islamic Republic of Iran. ${ }^{4}$ School of Nursing and Midwifery, Iran University of Medical Sciences, Tehran, Islamic Republic of Iran. (Correspondence to: Maryam Rassouli: Rassouli.m@gmail.com).

\begin{abstract}
Background: Cancer in children causes many challenges for the family. When a refugee family experiences it, its impacts may be different and more specific considerations for care may be needed.

Aims: This study aimed to explore the experiences of Afghan mothers living in the Islamic Republic of Iran who had a child with cancer.

Methods: This was a qualitative study, conducted in 2017, of Afghan refugee women with children diagnosed with cancer and referred to a cancer referral hospital in Tehran; they were selected through purposive sampling. Face-to-face, semi-structured and in-depth interviews were conducted for data collection until data saturation was reached. Conventional content analysis was done. MAXQDA 10 was used for organizing the data.

Results: Nine Afghan mothers were interviewed. They were aged 24-44 years and the children were aged 2-9 years. A primary theme called "passive acceptor" was found with five subthemes: chronic suffering, health issues, lack of skills, maladaptive coping and enthusiasm. The mothers were struggling to cope with the challenges of caring for a child with cancer both financially, physically and emotionally.

Conclusion: In spite of many issues in common with similar groups in other countries, Afghan mothers appear to need to greater assistance when it comes to seeking help and understanding for the care for their child with cancer, possibly because of cultural barriers to self-empowerment. Tailored care plans are recommended for Afghan refugee mothers in the Islamic Republic of Iran.

Keywords: Refugees, cancer, children, mothers, qualitative research, Iran

Citation: Nikfarid L; Rassouli M; Shirinabadi Farahani A; Beykmirza R; Khoubbin Khoshnazar TA.. Perspectives of Afghan refugee mothers on the experience of caring for a child with cancer: a qualitative analysis. East Mediterr Health J. 2020; 26(6):680-686. https://doi.org/10.26719/emhj.19.055 Received: 31/05/18; accepted: 14/10/18

Copyright (C) World Health Organization (WHO) 2020. Open access. Some rights reserved. This work is available under the CC BY-NC-SA 3.o IGO license (https://creativecommons.org/licenses/by-nc-sa/3.o/igo).
\end{abstract}

\section{Introduction}

Although the number of children with cancer is growing, the outcomes of the disease have improved as a result of new treatment methods $(1,2)$. However, financial problems, uncertainty, inability to define the illness and its outcomes, and other psychological problems in the family of a child with cancer have been frequently reported as major challenges (3-6). Mothers use different ways to adapt to these challenges, which are affected by internal and external factors (7).

The increasing numbers of immigrant refugees is a global problem that affects many countries, including the Islamic Republic of Iran, where most Afghan refugees migrate. About two million legal Afghan immigrants live in the country (8). Political and economic problems are the most common causes of the immigration of Afghans to the Islamic Republic of Iran over the past 37 years. As well as the immigration-related challenges, such as illiteracy and poverty (especially for illegal immigrants) (9), chronic diseases in children put Afghan refugees under a much greater level of stress (8). The quality of life in such a family, especially for the mother, is reported to be below average (10). No research has been conducted in the Islamic Republic of Iran on the challenges Afghan immigrant families face when caring for a child with cancer.

Given the large number of immigrants in the country and the moral obligation of receiving countries to provide them with health services, information on the effects on Afghan refugee mothers in the Islamic Republic of Iran of caring for a child with cancer would be useful. Data from such a study would make it possible to plan more comprehensive family-centred care for such families. In addition, it would provide the opportunity to help improve the quality of life of these mothers and, consequently, that of the child with cancer. The purpose of this study therefore was to assess the experience of Afghan mothers while caring for a child with cancer.

\section{Methods}

\section{Study design and sample}

This was a qualitative descriptive study conducted from April to July 2017 to explore the experience of Afghan mothers who had to care for a child with cancer. Conventional content analysis was done (11). The study setting 
was a paediatric teaching hospital in Tehran. The participants were purposively selected if they met the following criteria: had a child with a definite diagnosis of cancer (not in the end stage or in intensive care), lived with the spouse, spoke Farsi and had no history of mental illness (self-reported). Participants were met by the research team during their visit to the outpatient department of the hospital or during their child's hospitalization. Since two of the researchers in this study regularly attended the hospital as nursing instructors and knew most of the patients and their families, a good relationship had already been formed between them and the participants.

\section{Data collection and analysis}

Data were collected through semi-structured in-depth interviews. Interviews were recorded and transcribed, and then listened to again to ensure the accuracy of the transcriptions. MAXQDA software, version 10.0 was used to manage the textual data. To analyse the data, a constant comparative method (12) was used which included the following steps based on descriptive content analysis (11). Each interview text was read several times; meaning units (a unit of analysis) were identified from which important points in the texts were extracted in order to consider the implicit and explicit contents of the meaning units (open coding). These codes were then classified under broader titles based on their similarities and differences (grouping and categorizing). This process continued until the main and secondary themes were extracted (abstraction).

In order to evaluate the soundness of our qualitative research, three criteria were used after the analysis - credibility, dependability and transferability (13,14). Credibility of the data could be achieved through the researchers' familiarity with the participants over a long period of time. Credibility was boosted by member checking and peer debriefing. An audit trail, themes, subthemes and descriptions were used in order to record the participants' experiences, which helped boost dependability. To ensure transferability, the study documents were kept safe and efforts were made to explain the study methodology as extensively as possible in order to ensure the application of this research method to other settings $(13,14)$.

\section{Ethical considerations}

The mothers were informed about the aims of the study and their informed consent obtained. Participants had the right to leave the study at any stage. The ethics committee of Shahid Beheshti University of Medical Sciences approved the study.

\section{Results}

Interviews were conducted with nine mothers aged 2444 years. Their children were aged2-9 years. One of the mothers had immigrated to the Islamic Republic of Iran the previous year for treatment; the rest had been living in the country for more than 12 years and their children had been born there. Except for one mother, their spouses were labourers or vendors, who were either illiterate or had elementary education. The types of cancer identified were rhabdomyosarcoma, leukaemia and Wilms tumour.

Results were categorized under one main theme "passive acceptor", and five secondary themes: chronic suffering; maladaptive coping; health issues; lack of skills and enthusiasm (Table 1).

The participants who appeared as passive acceptors were those who had tried to fight the situation caused by their child's cancer, which had added many problems to their lives. However, they did not have adequate or appropriate coping mechanisms, or social and financial resources to help them through this journey. They found

\begin{tabular}{|c|c|c|c|}
\hline Main theme & Secondary themes & Subthemes & Meaning of units \\
\hline \multirow{11}{*}{$\begin{array}{l}\text { Passive } \\
\text { acceptor }\end{array}$} & \multirow{3}{*}{ Chronic suffering } & $\begin{array}{l}\text { Shadow of previous } \\
\text { frightening experiences }\end{array}$ & Being upset by memories, not willing to go back to Afghanistan \\
\hline & & Multiple problems ahead & $\begin{array}{l}\text { Poor economic circumstances, unemployment of the } \\
\text { father, fear of husband becoming addicted to drug }\end{array}$ \\
\hline & & Livelihood difficulties & $\begin{array}{l}\text { Living in an uncomfortable house, being far from the } \\
\text { basic health care facilities, low income }\end{array}$ \\
\hline & \multirow[b]{2}{*}{ Health issues } & Lack of self-care & Not having visits for health care, not being familiar with coping methods \\
\hline & & Neglect of own health & $\begin{array}{l}\text { Not following up treatment for health problems, } \\
\text { forgetting to get medicines prescribed by physicians }\end{array}$ \\
\hline & \multirow{2}{*}{ Lack of skills } & $\begin{array}{l}\text { Inability to manage care of the } \\
\text { child }\end{array}$ & $\begin{array}{l}\text { Being dependent on others to follow the care of the child, } \\
\text { not having enough information about the care of the child }\end{array}$ \\
\hline & & $\begin{array}{l}\text { Constant fear of making } \\
\text { mistakes }\end{array}$ & $\begin{array}{l}\text { Increasing feelings of anxiety when the child needs to be visited, } \\
\text { not being able to read the prescriptions on drugs }\end{array}$ \\
\hline & \multirow{2}{*}{ Maladaptive coping } & $\begin{array}{l}\text { Maintaining the current } \\
\text { situation }\end{array}$ & $\begin{array}{l}\text { Trying to keep their current state unchanged as it seems safe, } \\
\text { avoiding new experiences in life }\end{array}$ \\
\hline & & Isolation & $\begin{array}{l}\text { Not having contacts with other mothers of children with cancer, } \\
\text { not trying to join social support systems in hospital }\end{array}$ \\
\hline & \multirow{2}{*}{ Enthusiasm } & $\begin{array}{l}\text { Belief in the effectiveness of } \\
\text { the care system and treatment }\end{array}$ & Having trust in the health care providers, not having any complaints \\
\hline & & Satisfaction with the service & $\begin{array}{l}\text { Praying for nurses and doctors, feeling happy when comparing with the care } \\
\text { available in Afghanistan, feeling lucky to be in the Islamic Republic of Iran }\end{array}$ \\
\hline
\end{tabular}


themselves trying to manage the situation and were happy to be in a better environment compared with their former one where they faced war and social injustice. However, their knowledge and actions were inadequate to lead to positive health outcomes for themselves and their children.

\section{Chronic suffering}

The memories of the war in Afghanistan have caused a pattern of chronic suffering in the Afghan women. A 37-year-old mother of a child with a Wilms tumour stated, "I remember the war and the planes that dropped bombs. I was playing with my friend, but we had to run away. I did not have slippers on my feet. We got to our mothers' tent. We saw that some people were killed. Fear is still in our hearts."

It would appear that even though these women came to the Islamic Republic of Iran at an early age, they have remained traumatized by their experiences. All the participants had bitter memories of war, death, fear, danger and displacement, as well as poverty, unemployment and loneliness in their adoptive country. The women were struggling with multiple social and financial issues long before the diagnosis of their child's cancer. Their child's illness raised many problems not dissimilar to those experienced by mothers of children with cancer in other countries. However, uncertainty, chronic sorrow and feelings of guilt about the sick child, as well as the financial burden, had exhausted these mothers. One mother stated, "Although I know it is not heaven here either, you are still afraid you may lose something again."

\section{Health issues}

Most of the participants, similar to their peers in the Islamic Republic of Iran, suffered from poor health even before the diagnosis of cancer in their child. This situation is the result of being refugees and the changes in their lifestyle due to immigration. However, the new challenge of their child's cancer had made their health worse in all dimensions. According to one mother, "I cannot sleep. I am stressed out. I say to myself, 'God, what is going to happen? Are they admitting my child to hospital again?' When I go to the hospital, I do not care about myself. I do not eat anything".

Headaches, depression and anxiety were some of the most frequent complaints of the mothers. Poverty, their spouse's unemployment, lack of access to health care and insurance problems were some of the obstacles mentioned that prevented them from seeking professional help. One mother said, "When I am here I hear from other mothers that we ourselves also need medication to keep our strength up."

\section{Lack of skills}

Most of the participants had found themselves in a situation where they were afraid of making mistakes and being unable to take care of their child. Illiteracy, inaccessibility to social network support, and lack of general knowledge and skills in various areas put them in a desperate state. The mother of a child with leukaemia stated, "If I take him home and I find he has a fever, can he stay at home? Or must he go to the hospital?" Most of the mothers were facing problems common to all families with a child with cancer, but they did not actively try to seek outside help, and they had insufficient resources to help them cope. Statements such as "Everyone knows that cancer is a disaster" were frequently heard from the mothers who did not have any hope of their childe recovering or faith in a happy future.

\section{Maladaptive coping}

Mothers were reluctant to actively engage in the child's treatment because of their lack of skills and knowledge as well as the many challenges they were facing. Therefore, they had passively surrendered to the reality of the disease. They would rather turn to spiritual support as an emotional coping mechanism and avoid problem-oriented coping strategies such as seeking out information or social support. The mothers considered religion as their only refuge and tried to improve the health of their child through prayer. They also believed that sins in their own lives had resulted in divine punishment in the form of their child's illness: "I thought that it is because of my sins. I thought it might have been the result of my own fault. Because of sinning, God did this to me." According to the mothers, they did not try to obtain information about the child's illness, although searching for information is considered a strategy to deal with stress. The mothers reported only a few adaptive coping methods used in their lives after the diagnosis of their child's disease. Most of the mothers showed signs of chronic depression and maladaptive coping methods, such as constant crying or feelings of isolation.

\section{Enthusiasm}

The mothers expressed satisfaction and confidence in the Iranian health system in their various statements. A 28-year-old mother said, "Iran is very good. $80 \%$ of the costs are paid by benefactors. In Afghanistan, patients have to cover all the expenses themselves. There is no such a thing as charity there." The mothers also expressed their satisfaction with the services and the lack of discrimination between them and Iranian patients. One of them pointed out that, "Wherever you go in Iran, they call my child by his name. I like this. It seems that for them, we are the same as others."

\section{Discussion}

We assessed the perception of Afghan immigrant mothers in the Islamic Republic of Iran of their experience of having a child with cancer. Although the results were similar to the findings of other studies conducted on the topic, especially in Middle Eastern countries $(5,15,16)$, there were some differences and thus further research is needed in this regard to understand the reasons for these differences.

The analysis of the data led to the emergence of the main category: passive acceptor. Although submission to God's will is considered a category in many studies on 
mothers with children with cancer $(5,15,16)$, our finding of the acceptance of the child's cancer without trying to actively deal with it is new. Afghan women, according to their cultural and educational background, believe that illnesses and other tragic events come from God and that people have no choice but to accept it. In contrast, Lebanese parents described their experience of having a child with cancer as a battle (17), while in a study on Iranian mothers, the challenge of their child's cancer had forced them develop their capabilities and take an active role in the management of the disease (5). This may support the hypothesis that dealing with the cancer of a child is affected by many cultural factors.

For the secondary theme "chronic suffering", the memories of war and migration were still fixed in the minds of the mother who experienced it. This mentality has adverse effects that have been mentioned in other studies and manifest as psychological disorders (18-21). A far higher prevalence of psychological disorders such as post-traumatic stress disorder has been reported in Afghan refugees in the Islamic Republic of Iran compared with the Iranian population as a whole (22). These memories, which are a constant reminder of the insecurity of life during wartime, have created a permanent sense of suffering for the mothers. Studies conducted on refugee parents have found that they face many difficulties providing shelter and care for their children, a situation which may be made worse by the child's illness (23-25).

In addition, the unfavourable living conditions were a challenge these mothers had to face (18), as well as failure to address their own health issues - a common problem among Afghan refugees, especially among immigrant mothers. Studies show that the number of psychological problems is higher in mothers of immigrant families (26), yet immigrant mothers often refuse to admit their health problems because of a sense of shame (17), which is supported by the results of our study. The mothers also mentioned livelihood challenges as one of their main problems. This is also often reported by people regardless of asylum and immigration status, and was also noted in Syrian immigrant women with a child with cancer (27).

Although in another study, mothers emphasized shock, disbelief and crisis in their lives after receiving the diagnosis of their child's cancer, they all demonstrated different adaptive measures in order to deal with the change in their lives (5). What is striking in our study was the lack of any maternal desire for problem-solving and the recourse to religion as an emotional solution. Mothers showed no inclination to develop new skills, which is a common approach by mothers to manage a crisis in the family. New skills, such as problem-solving and resiliency, would help them to adapt and manage the consequences of the disease for the child and family more effectively. Getting help from peer groups and seeking social support by communicating with family members, relatives and friends are considered to be a coping strategy that is highly recommended $(28,29)$. Afghan mothers in our study, in spite of the presence of other mothers in similar circumstances, actively tried to isolate themselves and instead turned to prayer as a coping mechanism; this is widespread according to other studies (5,30-32).

The family is considered to be the caretaker and the care provider (33). Mothers suffer because of the burden of care of their child with cancer and this has a negative effect on their health as well as the well-being of their child (34). At the same time, the mother has an important role in improving her child's quality of life (35). In fact, supporting and helping mothers means extending care to the child and offers better chances of recovery. In our study, mothers caring for children with cancer had completely neglected their own health in their devotion to taking care of their children. In addition, mothers were trying to shield their husbands from the realities of the situation in order to avoid tensions because they were worried that their husbands would not be able to cope and might turn to drugs. This finding is similar those in other studies $(4,5)$. For each mother, protecting the husband meant avoiding the occurrence of another crisis, which is rooted in the popular cultural belief of the community: as mentioned by one woman, "Men turn to addiction to get away from household problems, otherwise they might have a stroke". Thus, the strain on mothers is relentless, not only keeping the husband away from issues of the child's cancer but also bearing the burden of care giving.

The lack of skills was another subtheme of the study indicating the inactive role of Afghan mothers in managing their child's cancer at home, looking after their own health or that of others. This could have a cultural basis due to the fact that Afghan women in the Islamic Republic of Iran do not engage in activities that empower their role in the family and society. Traditionally, most Afghan men do not allow their wives to have a job or participate in social activities (36).

One of the findings of our study, which does not concur with findings elsewhere, was the lack of discrimination in health services by medical personnel in the Islamic Republic of Iran. Afghan women have a low level of education and have been the victims of religious extremism, isolation and discrimination (8). A number of studies in the Islamic Republic of Iran, reported that Afghan women had a sense of discrimination at health centres when receiving childbirth services (7). The reason for the difference in our finding may be a difference in communication style between the staff and the mother when it is a question of a child's sickness rather than childbirth. Centres such as Mahak paediatric hospital offer their services to all children with cancer without discrimination. However, lack of complaint by Afghan refugee mothers about medical services differs from studies on the Iranian population $(4,37,38)$, who were likely to complain more.

\section{Conclusion}

Cultural discrimination causes inequalities, misconceptions and promotion of stereotypes in the provision of care and the treatment of patients. Avoidance of discrimination 
is essential for equitable treatment of Afghan mothers, who appear to need to greater assistance when it comes to seeking help and understanding for the care for their child with cancer, possibly because of cultural barriers to self-empowerment. Therefore, tailored care plans are required for Afghan refugee mothers in the Islamic Republic of Iran.

Given that the challenges associated with the health of immigrants and refugees are everyday issues in the
Middle East and North Africa, a collaborative effort could be considered to train care providers in care provision for refuges, and an understanding of their disease-coping strategies and culturally based perceptions of their physical and mental health. Such training could help to promote the health of refugee mothers who have a child with cancer.

Funding: None.

Competing interests: None declared.

\section{Point de vue des mères afghanes réfugiées sur l'expérience de prise en charge d'un enfant atteint d'un cancer : une analyse qualitative}

\section{Résumé}

Contexte : Le cancer de l'enfant entraîne de nombreuses difficultés pour une famille. Lorsque cela touche une famille réfugiée, les conséquences peuvent être différentes et des considérations plus spécifiques en matière de soins peuvent être nécessaires.

Objectifs : La présente étude visait à étudier les expériences de mères afghanes vivant en République islamique d'Iran ayant un enfant atteint d'un cancer.

Méthodes : Il s'agissait d'une étude qualitative menée en 2017 auprès de femmes afghanes réfugiées ayant un enfant pour lequel un diagnostic de cancer avait été posé et ayant été orientées vers un hôpital de recours à Téhéran ; celles-ci ont été sélectionnées au moyen d'un échantillonnage par choix raisonné. Des entretiens en présentiel, semi-structurés et approfondis ont été menés pour la collecte des données jusqu'à saturation. L'analyse de contenu conventionnelle a été effectuée. Le logiciel MAXQDA 10 a été utilisé pour organiser les données.

Résultats : Neuf mères afghanes ont été interrogées. Elles étaient âgées de 24 à 44 ans et les enfants avaient entre 2 et 9 ans. Un thème principal intitulé « acceptation passive » a été défini et complété par cinq sous-thèmes : la souffrance chronique, les problèmes de santé, le manque de compétences, l'inaptitude à faire face et l'enthousiasme. Les mères avaient du mal à faire face aux difficultés financières, physiques et émotionnelles liées à la prise en charge d'un enfant atteint d'un cancer.

Conclusion : En dépit de nombreux problèmes communs avec des groupes similaires dans d'autres pays, les mères afghanes semblent avoir besoin d'une assistance plus importante lorsqu'il s'agit de chercher de l'aide et de comprendre la prise en charge dont leur enfant atteint d'un cancer a besoin, peut-être en raison d'obstacles culturels qui empêchent l'autonomisation. Il est recommandé d'élaborer des plans de soins adaptés aux besoins des mères réfugiées afghanes qui vivent en République islamique d'Iran.

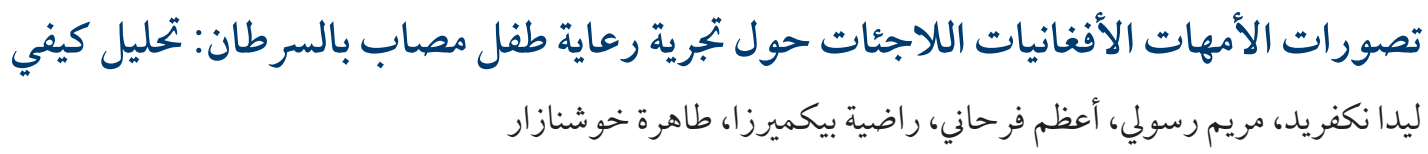
الخلاصة

الخلفية: يتسبب السرطان في تحديات عديدة للأسرة. وعندما تمر أسرة لاجئة بهكذا تحدي، فقد تتفاوت الآثار المترتبة عليه، وقد يتطلب ذلك توجيه مزيد من الاعتبار ات الخاصة للرعاية.

الأهداف: هدفت هذه الدر اسة إلى استطلاع تجارب الأمهات الأفغانيات اللواتي يعشن في جمهورية إيران الإسلامية ولديهن طفل مصاب بالسرطان.

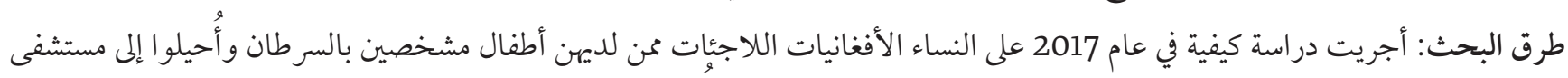

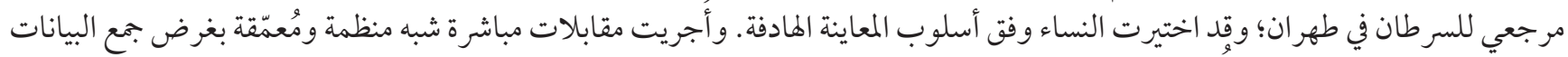

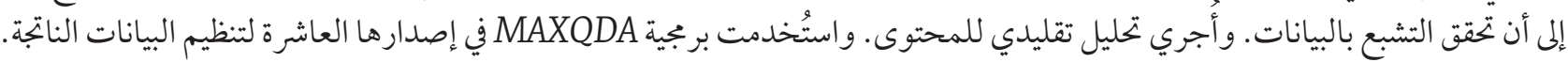

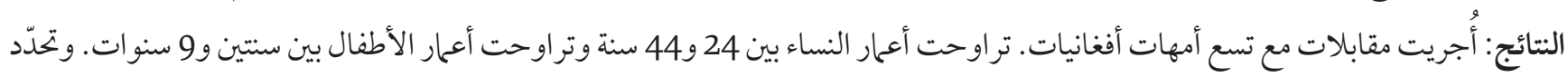

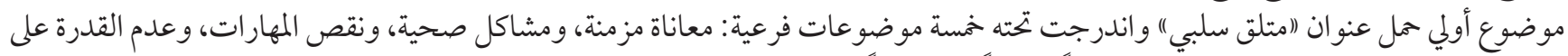

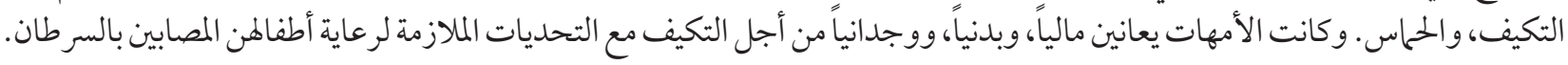




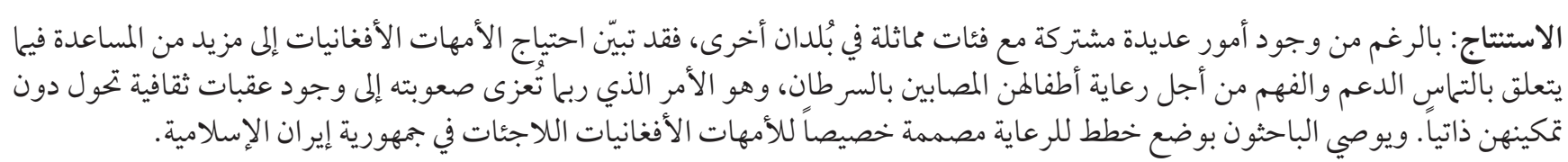

\section{References}

1. Beykmirza R, Nikfarid L, Atashzadeh-Shoorideh F, Nasiri M. Nursing adherence to ethical codes in pediatric oncology wards. Nursing ethics. 2017:0969733017730683.

2. Khanali Mojen L, Rassouli M, Eshghi P, Zendedel K, Akbari Sari A, Heravi Karimooi M, et al. Pediatric Palliative Care in Iran: Applying Regionalization of Health Care Systems. Asian Pacific journal of cancer prevention : APJCP. 2018;19(5):1303-11.

3. Mojen LK, Rassouli M, Eshghi P, Sari AA, Karimooi MH. Palliative care for children with cancer in the Middle East: A comparative study. Indian journal of palliative care. 2017;23(4):379.

4. Nemati S, Rassouli M, Ilkhani M, Baghestani AR. Perceptions of family caregivers of cancer patients about the challenges of caregiving: a qualitative study. Scandinavian journal of caring sciences. 2018;32(1):309-16.

5. Nikfarid L, Rassouli M, Borimnejad L, Alavimajd H. Experience of chronic sorrow in mothers of children with cancer: A phenomenological study. European Journal of Oncology Nursing. 2017;28:98-106.

6. Sajjadi M, Rassouli M, Abbaszadeh A, Alavi Majd H, Zendehdel K. Psychometric properties of the Persian version of the Mishel's Uncertainty in Illness Scale in patients with cancer. European journal of oncology nursing : the official journal of European Oncology Nursing Society. 2014;18(1):52-7.

7. McNeill T, Nicholas D, Beaton J, Montgomery G, MacCulloch R, Gearing R, et al. The coconstruction of couples' roles in parenting children with a chronic health condition. Qualitative health research. 2014;24(8):1114-25.

8. Mohammadi S, Gargari SS, Fallahian M, Källestål C, Ziaei S, Essén B. Afghan migrants face more suboptimal care than natives: a maternal near-miss audit study at university hospitals in Tehran, Iran. BMC pregnancy and childbirth. 2017;17(1):64.

9. Rezaeian M. A review on the book "Human Geography: People, Place and Culture". Journal of Rafsanjan University of Medical Sciences. 2014;13(6):577-8.

10. Link CJ, Fortier MA. The relationship between parent trait anxiety and parent-reported pain, solicitous behaviors, and quality of life impairment in children with cancer. Journal of pediatric hematology/oncology. 2016;38(1):58-62.

11. Schreier M. Qualitative content analysis in practice: The SAGE handbook of qualitative data analysis; 2012.

12. Graneheim UH, Lundman B. Qualitative content analysis in nursing research: concepts, procedures and measures to achieve trustworthiness. Nurse education today. 2004;24(2):105-12.

13. Polit DF, Beck CT. Essentials of Nursing Research: Appraising Evidence for Nursing Practice: Philadelphia, PA: LippincottWilliams\&Wilkins 2013.

14. Lincoln YS, Guba EG. But is it rigorous? Trustworthiness and authenticity in naturalistic evaluation. New Directions for Program Evaluation. 1986;1986(30):73-84.

15. Iranmanesh S, Shamsi A, Dehghan M. Post-traumatic stress symptoms among iranian parents of children during cancer treatment. Issues in mental health nursing. 2015;36(4):279-85.

16. Zafarian Moghaddam E, Behnam Vashani H, Reihani T, Namazi Zadegan S. The Effect of Spiritual Support on Caregiver's Stress of Children Aged 8-12 with Leukemia Hospitalized in Doctor Sheikh Hospital in Mashhad. Future of Medical Education Journal. 2016;6(2):19-25.

17. Khoury MN, Huijer HA-S, Doumit MAA. Lebanese parents' experiences with a child with cancer. European Journal of Oncology Nursing. 2013;17(1):16-21.

18. Alemi Q, James S, Cruz R, Zepeda V, Racadio M. Psychological distress in Afghan refugees: A mixed-method systematic review. Journal of immigrant and minority health. 2014;16(6):1247-61.

19. Groen SP, Richters A, Laban CJ, Devillé WL. Cultural identity among Afghan and Iraqi traumatized refugees: Towards a conceptual framework for mental health care professionals. Culture, Medicine, and Psychiatry. 2018;42(1):69-91.

20. Panter-Brick C, Grimon MP, Eggerman M. Caregiver-Child mental health: A prospective study in conflict and refugee settings. Journal of Child Psychology and Psychiatry. 2014;55(4):313-27.

21. Panter-Brick C, Grimon MP, Kalin M, Eggerman M. Trauma memories, mental health, and resilience: A prospective study of Afghan youth. Journal of Child Psychology and Psychiatry. 2015;56(7):814-25.

22. Drožđek B, Kamperman AM, Tol WA, Knipscheer JW, Kleber RJ. Seven-year follow-up study of symptoms in asylum seekers and refugees with PTSD treated with trauma-focused groups. Journal of clinical psychology. 2014;70(4):376-87.

23. Kebudi R, Bayram I, Yagci-Kupeli B, Kupeli S, Sezgin G, Pekpak E, et al. Refugee children with cancer in Turkey. The Lancet Oncology. 2016;17(7):865-7.

24. Pergert P, Ekblad S, Björk O, Enskär K, Andrews T. Resourcing: An approach used by foreign-born parents struggling on in childhood cancer care. European Journal of Oncology Nursing. 2016;23:1-7. 
25. Soykoek S, Mall V, Nehring I, Henningsen P, Aberl S. Post-traumatic stress disorder in Syrian children of a German refugee camp. The Lancet. 2017;389(10072):903-4.

26. Arabiat DH, Altamimi A. Unmet care needs of parents of children with cancer in Jordan: implications for bed-side practice. Journal of clinical nursing. 2013;22(3-4):531-9.

27. Silbermann M, Daher M, Kebudi R, Nimri O, Al-Jadiry M, Baider L. Middle eastern conflicts: implications for refugee health in the European Union and middle eastern host countries. Journal of global oncology. 2016;2(6):422-30.

28. Compas BE, Bemis H, Gerhardt CA, Dunn MJ, Rodriguez EM, Desjardins L, et al. Mothers and fathers coping with their children's cancer: Individual and interpersonal processes. Health Psychology. 2015;34(8):783.

29. Monti JD, Winning A, Watson KH, Williams EK, Gerhardt CA, Compas BE, et al. Maternal and Paternal Influences on Children's Coping with Cancer-Related Stress. Journal of child and family studies. 2017;26(7):2016-25.

30. Abu-Raiya H, Hamama L, Fokra F. Contribution of religious coping and social support to the subjective well-being of Israeli muslim parents of children with cancer: a preliminary study. Health \& Social Work. 2015;40(3):83-91.

31. Hildenbrand AK, Alderfer MA, Deatrick JA, Marsac ML. A mixed methods assessment of coping with pediatric cancer. Journal of psychosocial oncology. 2014;32(1):37-58.

32. Hullmann SE, Fedele DA, Molzon ES, Mayes S, Mullins LL. Posttraumatic growth and hope in parents of children with cancer. Journal of psychosocial oncology. 2014;32(6):696-707.

33. Conway MF, Pantaleao A, Popp JM. Parents' Experience of Hope When Their Child Has Cancer: Perceived Meaning and the Influence of Health Care Professionals. Journal of Pediatric Oncology Nursing. 2017;34(6):427-34.

34. Williams PD, Williams KA, Williams AR. Parental caregiving of children with cancer and family impact, economic burden: Nursing perspectives. Issues in comprehensive pediatric nursing. 2014;37(1):39-60.

35. Sulkers E, Tissing WJ, Brinksma A, Roodbol PF, Kamps WA, Stewart RE, et al. Providing care to a child with cancer: a longitudinal study on the course, predictors, and impact of caregiving stress during the first year after diagnosis. Psycho-Oncology. 2015;24(3):318-24.

36. Kandiyoti D. Old Dilemmas or New Challenges? The Politics of Gender and Reconstruction in Afghanistan. Development and Change. 2007;38(2):169-99.

37. Sajjadi H, Roshanfekr P, Asangari B, Gharai N, Torabi F. Quality of life and satisfaction with services in caregivers of children with cancer. Iran Journal of Nursing. 2011;24(72):8-17.

38. Taleghani F, Fathizadeh N, Naseri N. The lived experiences of parents of children diagnosed with cancer in Iran. European journal of cancer care. 2012;21(3):340-8. 